\title{
ANALISA ZAKAT DAN INSTRUMEN SEJENIS TERHADAP SISTEM FISKAL ISLAM
}

\author{
Anton Hindardjo ${ }^{1}$ \\ notna.ah@gmail.com
}

\section{Abstraction}

The influence of zakat ensures that economic activities can run at a minimum level, namely at the level of meeting primary needs, where zakat, infaq-shadaqah and other similar instruments encourage aggregate demand, because its function is to help the ummah to reach the standard of living above the minimum level. In Islamic Fiscal Policy $C=C o+b$ $Y d, Y d=Y-Z a k a t+\operatorname{Tr}(8$ asnaf $), I S=C+I+G+(X-M)$. Infak-shadaqah and similar instruments are through bitul mal used to alleviate poverty through development programs. So zakat and infa-shadaqah have their respective roles. In the condition of the good ummah where the level of faith is at a good level, the state income derived from the infaq-shadaqah should be greater than the receipt of zakat. Guarantee in the mechanism of zakat is a top priority in economic policy (when zakat is not able to fulfill the guarantee function, then state revenues from sources other than zakat will be used until the minimum needs of all people are fulfilled).

Key Word: Zakat, Islamic Fiscal, justice

\section{A. Pendahuluan}

Substansi fiskal dalam ekonimi Islam telah dilakukan sejak Rosulloh di Madinah, secara teoritis pebedaan antara fiscal konvensional dan fiscal Islam terletak pada tataran substansi. Dengan demikian tentu saja kebijakan fiscal Islam berbeda 180 derajat dengan kebijakan fiskal dalam negara kapitalis, seperti dari aspek hukum pengambilan kebijakan fiskalnya, struktur penerimaan dan pengeluaran negara, politik ekonomiyang melandasi sistem fiscal.

Sistem ekonomi Islam, dalam hal kebijakan fiskal pemerintah disektor riil ekonomi begitu jelas terlihat. Dimana tergambar bagaimana instrumen fiskal Islam begitu mendominasi pembahasan ekonomi para pakar ekonomi Islam klasik. Apalagi pilar utama dan pertama Al Qur'an dalam perekonomian Islam menyebutkan mekanisme fiskal zakat menjadi syarat dalam perekonomian ini.

\footnotetext{
${ }^{1}$ Dosen Tetap Prodi Muamalah STAI Asy-Syukriyyah
} 
“Ambillah zakat dari sebagian harta mereka, dengan zakat itu kamu membersihkan dan mensucikan mereka, dan mendoalah untuk mereka, sesungguhnya doa kamu itu (menjadi) ketentraman jiwa bagi mereka. Dan Allah Maha Mendengar lagi Maha Mengetahui. " (At Taubah : 103)

Instrumen fiskal merupakan alat bagi negara untuk menjalankan perekonomian menuju kesejahteraan material dan spiritual, baik yang disyaratkan secara syariah maupun yang dilakukan sesuai wewenang negara. Instrumen fiskal yang menjadi syarat secara syariah misalnya mekanisme zakat. Sedangkan instrumen-instrumen yang menjadi wewenang negara dalam menentukan pemberlakuan, besar dan objek instrumen fiskal, misalnya Ushur, Infaq-Shadaqah-Wakaf, Ghanimah, Khums, Fay',Pajak Khusus dan lain sebagainya.

Dimana salah satu instrumen fiskal berupa Zakat dalam konteks kontemporer telah mengalami reformasi konsepsi operasional zakat. Pada saat ini, dana zakat tidak hanya dibagikan secara terbatas kepada delapan golongan penerimaan zakat saja (mustahiq), yang diartikan secara sempit. Namun konsepsi ini telah diperluas cakupannya, meliputi segala upaya produktif, yang tidak hanya diperuntukkan sebagai kaum dhu'afa, tetapi juga telah dikembangkan sebagai upaya pengentasan kemiskinan dan pemberdayaan ekonomi ummat. Dan dalam pelaksanaan operasionalnya mesti mendapat dukungan secara multi dimensional, baik aspek politik, hukum, ekonomi dan sebagai masalah ekonomi semata, tetapi sebagai persoalan multi aspek.

\section{B. Landasan Teori Tentang Zakat}

Zakat merupakan pilar utama dalam sistem dan instrumen orisinil dari sistem ekonomi Islam. Hakikat dan fungsi zakat bertugas mendistribusikan kekayaan pada golongan masyarakat yang membutuhkan. Dengan keyakinan bahwa pada tiap harta yang didapatkan oleh seseorang terdapat didalamnya hak para fakir miskin dan orang-orang yang kekurangan (8 asnaf).

"Sesungguhnya zakat-zakat itu, hanyalah untuk orang-orang fakir, orang-orang miskin, pengurus-pengurus zakat, para mu'allaf, yang dibujuk hatinya untuk memerdekakan budak, orang-orang yang berhutang, untuk (yang berjihad) dijalan Allah dan orangorang yang sedang dalam perjalanan, sebagai suatu ketetapan yang diwajibkan Allah; dan Allah Maha Mengetahui lagi Maha Bijaksana.” (At Taubah: 60) 


\section{Jurnal Asy-Syukriyyah}

Meskipun perintah zakat atau mekanisme zakat sudah turun bersama surat-surat Al-Qur'an di Makkah (Makiyah), namun pelaksanaan zakat secara efektif dan komprehensif baru dilakukan setelah 18 bulan atau tahun kedua setelah Hijrah. Dengan kata lain zakat baru diimplementasikan di Madinah. Pada masa tersebut sudah menjadi kelaziman para mustahiq umumnya memperoleh satu dirham perharinya untuk memenuhi kebutuhan mereka. Jumlah ini juga yang menjadi rujukan tingkat upah bagi tenaga kerja yang tidak memiliki keterampilan atau keahlian (unskill labor). ${ }^{2}$

Eksistensi zakat dalam kehidupan manusia baik pribadi maupun kolektif, pada hakikatnya memiliki dua alasan utama, yaitu alasan ibadah dan alasan ekonomi. Alasan ibadah mengungkapkan bahwa eksistensi zakat merupakan salah satu variable atau ukuran bagi kepatuhan seseorang pada Allah SWT. Artinya zakat merupakan bentuk ibadah wajib bagi mereka yang berada pada posisi yang baik dilihat dari kepemilikan harta. Sementara alasan ekonomi adalah alasan yang mengungkapkan bahwa zakat merupakan variable utama dalam menjaga kestabilan sosial ekonomi. Dengan adanya zakat ekonomi akan terus dijaga agar ada pada posisi aman untuk terus berlangsung, sekaligus menjaga stabilitas sosial pergaulan diantara manusia, antara para pelaku pasar atau antara si kaya dan si miskin.

\section{Zakat dan Implikasinya dalam Perekonomian}

Instrumen Fiskal dimana zakat menjadi sistem yang wajib (obligatory zakat system) bukan sistem yang sukarela (volutary zakat system). Konsekwensi dari system ini adalah pengakuan secara kostitusional diturunkan dalam wujud institusi negara yang bernama baitul mal (treasury house). Fungsi pertama dari Instrumen fiskal berupa zakat adalah menjamin terpenuhinya kebutuhan hidup minimal (guarantee of a minimum level of living). Institusi yang bernama baitul mal-lah yang memiliki tugas menjalankan fungsi fiskal yang mempengaruhi keseimbangan dalam pasar IS (Pasar Barang).

Mekanisme instrumen fiskal berupa zakat memastikan aktifitas ekonomi dapat berjalan pada tingkat yang minimal yaitu pada tingkat pemenuhan kebutuhan primer, sedangkan infak-shadakah dan intsrumen sejenis lainnya mendorong agregat demand bergeser kekanan dan berdampak kepada pendapatan nasional, karena fungsinya yang

\footnotetext{
${ }^{2}$ Monzer Kahf, The Performance of the institution of Zakah in Theory and Practice, The International Conference on Islamic Economics Towards the $21^{\text {st }}$ Century, Kuala Lumpur - Malaysia, April, 1999.
} 
membantu ummat untuk mencapai taraf hidup diatas tingkat minimum. Karena oleh instrumen infak-shadaqah dan instrumen sejenisnya inilah yang melalui bitul mal digunakan untuk mengentaskan kemiskinan melalui program-program pembangunan. Secara nilai dan fungsi zakat dan infak-shadaqah memiliki mekanisme masing-masing. Pada kondisi ummat yang baik dimana mempunyai kesadaraan syariah dan tingkat keimanannya ada pada level yang tertentu, efeknya pendapatan negara yang bersumber dari infak-shadaqah akan berkembang dimana memungkinkan lebih besar dari penerimaan zakat.

Instrumen fiskal berupa zakat dapat digunakan sebagai perisai bagi perekonomian agar tidak terpuruk pada kondisi krisis dimana kemampuan konsumsi mengalami stagnasi (underconsumption). Zakat memungkinkan perekonomian terus berjalan pada tingkat yang minimum, akibat penjaminan konsumsi kebutuhan dasar melalui baitul mal menggunakan akumulasi dana zakat. Bahkan Metwally ${ }^{3}$ mengungkapkan bahwa Zakat berpengaruh cukup positif pada ekonomi, karena instrumen zakat akan mendorong investasi dan menekan penimbunan uang (harta). Sehingga zakat memiliki andil dalam meningkatkan pertumbuhan ekonomi secara makro.

Pengaruh zakat terhadap perekonomian ini sebenarnya dapat dijelaskan menggunakan pendekatan moneter $(\mathrm{MV}=\mathrm{PT})$ yang dimiliki aliran moneteris dalam ekonomi konvensional ${ }^{4}$. Moneteris menyebutkan bahwa dengan asumsi velocityof money $(\mathrm{V})^{5}$ tetap dan full employment $(\mathrm{Y})$ terpenuhi, ekonomi akan tumbuh melalui kebijakan peningkatan money stock (M) melalui peningkatan harga (P). Paul Samuelson (1992) dalam bukunya macroeconomics, menunjukkan bagaimana GNP meningkat melebihi peningkatan $\mathrm{M}$, sehingga disimpulkan pertumbuhan ekonomi tersebut berasal dari

\footnotetext{
${ }^{3}$ Ziauddin Ahmed, Munawar Iqbal and Fahim Khan (Editors), Money and Banking In Islam, International Center for Research In Islamic Economics, King Abdul Aziz University Jeddah and Institute of Policy Studies Islamabad, Pakistan, 1996, pp. 17-18.

${ }^{4}$ Lihat catatan kaki no. 11 Umer Chapra, Monetary Policy in An Islamic Economy, Money and Banking in Islam (Edited by Ziauddin Ahmed, Munawar Iqbal, Fahim Khan), International Center for Research In Islamic Economics, King Abdul Aziz University Jeddah and Institute of Policy Studies Islamabad, Pakistan, 1996, pp. 34.

${ }^{5}$ Konsep ini diperkenalkan oleh Alfred Marshal dari Cambridge University dan Irving Fisher dari Yale University. Lihat Paul A. Samuelson dan William D. Nordhaus, Microeconomics (Terjemahan), Fourteen Edition, McGraw-Hill, Erlangga Jakarta, 1992.
} 
peningkatan $\mathrm{V}^{6}$. Dan zakat pada dasarnya dapat mempengaruhi perekonomian tersebut melalui penjagaan tingkat velocity of money (tingkat percepatan perpindahan uang). Apalagi velocity of money dapat terus didorong dengan keberadaan sektor social dalam perekonomian Islam.

\section{Gambar Kurva Relevansi IS-LM}

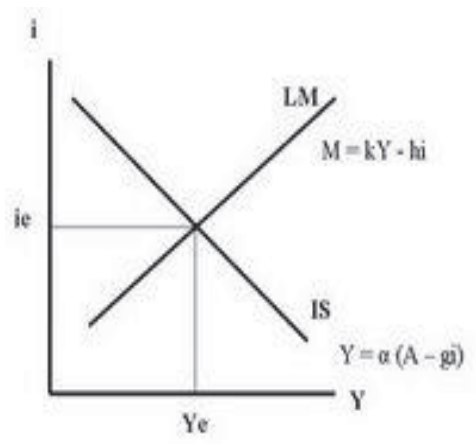

Keseimbangan umum dalam ekonomi selama ini dikenal sebagai kondisi keseimbangan antara dua pasar utama dalam ekonomi, yaitu pasar riil (barang dan jasa) dan pasar moneter (keuangan). Indicator (harga) utama dari keseimbangan umum ini adalah bunga. Keseimbangan umum ini menjadi tidak aplikatif (relevan) jika dijadikan rujukan dalam Islam. Alasan utama mengapa jenis keseimbangan umum ini tidak relevan adalah prinsip hukum (syariah) Islam yang melarang praktek bunga dalam ekonomi, karena bunga dikategorikan sebagai riba dalam Islam. Absensi bunga ini tentu membuat salah satu pasar utama dalam perekonomian konvensional, yaitu pasar moneter menjadi tidak relevan dalam pembahasan keseimbangan umum ekonomi Islam.

Terlebih lagi ada beberapa kelemahan yang memang melekat dalam penjelasan keseimbangan umum ekonomi konvensional, terutama kelemahan yang ditunjukkan oleh ketidak-konsistenan definisi dan peran bunga dalam pasar. Beberapa kelemahan tersebut diantaranya adalah berbagai harga pergerakan nilainya cenderung ditentukan yaitu merujuk pada penentuan suku bunga (interest free risk rate) oleh otoritas moneter, padahal sebagai harga sepatutnya bunga bergerak ditentukan oleh kekuatan pasar.

\footnotetext{
${ }^{6}$ Paul A. Samuelson dan William D. Nordhaus, Microeconomics (Terjemahan), Fourteen Edition, McGrawHill, Erlangga Jakarta, 1992.
} 
2. Bunga pada pasar barang (I) lebih berperan sebagai credit rate, sedangkan bunga pada pasar moneter $(\mathrm{Md})$ berperan sebagai saving rate. Padahal tidak pernah ada kondisi dimana credit rate sama dengan saving rate. Sehingga konsep tingkat bunga keseimbangan (ie) menjadi dipertanyakan definisinya atau relevansinya secara luas. Tingkat bunga keseimbangan tidak mewakili apa - apa kecuali sebuah asumsi saja. 3. Bunga sebagai credit rate yang tinggi menghambat uang mengalir ke pasar barang (menciptakan barang \& jasa), bunga sebagai saving rate yang tinggi mendorong uang menumpuk di sektor moneter (money creation \& concentration).

Dari analisa ini, diketahui secara teori model keseimbangan umum konvensional memiliki kelemahan, dimana model tersebut tidak menggambarkan keadaan apa yang sebenarnya terjadi di pasar. Kecenderungan bunga yang menggelembungkan jumlah uang (money creation) dan konsentrasi uang pada pemilik - pemilik dana (money concentration) tidak bias digambarkan oleh model ini. Padahal kecenderungan tersebut memiliki arah kepada ketimpangan sektoral antara moneter dan riil. Atau pada akhirnya dapat disimpulkan bahwa bunga pada dasarnya memiliki implikasi yang yang kontradiktif dengan prinsip - prinsip keseimbangan yang diinginkan oleh model ekonominya. Hal ini juga yang kemudian menjadi salah satu alasan mengapa bunga diyakini begitu berbahaya bagi perekonomian. Oleh sebab itu konsep keseimbangan umum ekonomi sepatutnya harus diletakkan pada definisi yang sebenarnya. Konsep keseimbangan umum ekonomi harus memiliki model yang secara valid mewakili definisinya. Untuk itulah Ekonomi Islam hadir memberikan jawaban atas permasalahan ini. Konsepsi Islam sebaiknya tidak dipandang sebagai sebuah konsep turunan dari kefanatisan atas sebuah keyakinan, tapi betul - betul sebuah konsep yang dilatarbelakangi oleh alasan ilmiah yang melekat padanya kebenaran. Karena kebenaran merupakan ciri - ciri dari suatu ilmu pengetahuan yang bermanfaat.

\section{Zakat \& Prilaku Konsumsi}

Perilaku konsumsi individu muslim terlihat dalam aplikasi zakat dalam kehidupannya dimana zakat merupakan instrumen ekonomi yang vital. Peniadaan mekanisme zakat dalam perekonomian akan merusak keseimbangan ekonomi, bahkan memiliki pengaruh yang besar pada ketidakseimbangan social.

Jika dilihat secara sekilas, orang lain mungkin melihat bahwa zakat memiliki tingkat korelasi yang negatif terhadap angka konsumsi. Pandangan ini muncul diakibatkan 
permasalahan zakat hanya berfokus pada golongan yang mengeluarkan zakat, sehingga dana yang seharusnya bisa digunakan untuk membeli barang konsumsi menjadi berkurang. Namun sebenarnya, jika dilihat dari sisi penerima zakat, maka akan menimbulkan korelasi yang cukup positif terhadap konsumsi. Jika dilihat dari kedua hal tersebut, sebenarnya yang cukup mempengaruhi model konsumsi makro.

Model konsumsi secara makro dalam Islam pada hakikatnya tidak berbeda dengan konvensional, yaitu model konsumsi yang ditentukan oleh konsumsi pokok (autonomous) dan konsumsi yang berasal dari pendapatan (income).

$$
\begin{aligned}
& \mathrm{C}=\mathrm{Co}+\mathrm{b} \text { Yd } \\
& \mathrm{Yd}=\mathrm{Y}-\mathrm{Zakat}+\operatorname{Tr}(8 \text { asnaf }) \\
& \mathrm{IS}=\mathrm{C}+\mathrm{I}+\mathrm{G}+(\mathrm{X}-\mathrm{M})
\end{aligned}
$$

Dimana :

C sama dengan total konsumsi,

Co konsumsi pokok,

$\mathrm{b}$ persentase dari income yang dikonsumsi (marginal propensity to consume; $M P C)$

$\operatorname{Tr}=$ pembayaran transfer (subsidi)

dan Y pendapatan.

I sama dengan Investasi

G Pengeluaran Pemerintah

X Ekspor

M Impor

Dari model tersebut, dapat dilihat bahwa peningkatan agregat konsumsi dasar (Co) akan meningkatkan total konsumsi. Jika dikaitkan dengan adanya zakat maka ketika adanya dana yang beredar ke tangan yang memiliki kemampuan ekonomi kurang maka peningkatan agregat konsumsi pokok akan lebih besar jika dibandingkan tidak adanya instrument zakat (uang hanya beredar pada orang yang mampu). Hal ini terkait pula dengan sikap dari orang yang mampu tersebut cenderung melakukan konsumsi untuk barang-barang sekunder atau mewah. Sedangkan orang yang memiliki kemampuan ekonomi kurang cenderung membelanjakan untuk kebutuhan pokok. 
Disisi lain, jika dilihat dari karakteristik elastisitas barang, maka elastisitas barangbarang sekunder atau mewah lebih inelastic jika dibandingkan dengan barang kebutuhan pokok. Dimana dalam hal ini, penambahan permintaan barang sekunder/mewah tidak cukup responsive terhadap perubahan harga, sementara penambahan barang kebutuhan pokok begitu responsif terhadap perubahan harga namun perubahan harga tidak mempengaruhi akan permintaan barang kebutuhan pokok karena seberapapun perubahan harga pada barang kebutuhan pokok akan tetap dikonsumsi oleh masyarakat. Jadi dalam hal ini, potensi konsumsi lebih terlihat jika adanya instrumentasi zakat yang membuat adanya sebagian dana yang beredar kepada orang yang memiliki kemampuan ekonomi lemah.

Secara kseluruhan, peningkatan konsumsi ini akan mendorong agregat peningkatan kinerja perekonomian yang dapat mendukung pertumbuhan dan pembangunan ekonomi

Zakat juga mempengaruhi pada MPC secara wajar, dengan asumsi bahwa perekonomian Islam menganjurkan prilaku konsumsi yang berhemat dan tidak bermewahmewah sehingga MPC ada pada tingkat yang relatif rendah atau wajar. Ini terlihata dari sisi muzakki, dalam pengenaan zakat akan menekan jumlah konsumsi agregat , karena zakat menurunkan jumlah pendapatan yang dapat dikonsumsi. Sehingga wajar jika kenaikan konsumsi golongan mustahik akibat zakat dapat terjadi, namun kenaikan tersebut akan dinetralisir oleh penurunan konsumsi golongan muzakki, sehingga agregat konsumsi relatif tidak berubah.

Perlu diingat bahwa kelebihan harta golongan mustahik memang punya potensi untuk diterjemahkan menjadi konsumsi jika tidak terkena zakat. Namun potensi untuk menjadi konsumsi itu lebih besar jika kelebihan harta (berupa zakat) itu ada di tangan golongan mustahik. Karena kelebihan harta ditangan golongan muzakki relatif untuk pembelian barang-barang sekunder atau mewah, sementara jika harta tersebut ditangan golongan mustahik, hampir pasti harta tersebut akan dibelanjakan untuk barang kebutuhan pokok.

Jadi jika dilihat dari potensi konsumsi yang akan terjadi, kelebihan harta berupa zakat sangat efektif atau potensial sekali berada di tangan mustahik dari pada muzakki. Sehingga dapat disimpulkan bahwa zakat akan mempengaruhi konsumsi secara positif. Selain itu diharapkan sebenarnya dalam jangka panjang zakat akan meningkatkan ekonomi 


\section{Jurnal Asy-Syukriyyah}

dan meningkatkan pendapatan perkapita, sehingga kekhawatiran efek negatif zakat terhadap ekonomi sangat tidak beralasan.।

Jadi dapat dikatakan bahwa pembahasan zakat dan kaitannya dengan makroekonomi tidak dapat dipisahkan dari fungsi utama zakat sebagai variable utama untuk peningkatan sisi permintaan (demand side) dari system ekonomi. Ini juga yang menjadi karakteristik lain dari perekonomian Islam, yaitu perhatian yang sama besar baik pada sisi permintaan maupun sisi penawaran, berikut dengan kelengkapan instrumeninstrumen yang dapat digunakan dalam memastikan keseimbangan diantara keduannya.

Peningkatan angka konsumsi ini selanjutnya secara keseluruhan (agregat) mendorong peningkatan kinerja perekonomian yang otomatis mendukung pertumbuhan dan

pembangunan ekonomi. Dengan demikian betullah apa yang sudah ditegaskan Allah SWT dalam firman-Nya:

“...Dan apa yang kamu maksudkan untuk mencapai keridhaan Allah, maka (yang berbuat demikian) itulah orang-orang yang melipatgandakan (pahalanya).” (Ar Rum: 39)

\section{Zakat dan Prilaku Produksi}

Zakat akan memelihara perekonomian, yang pada dasarnya akan berpengaruh baik pada konsumen maupun pada produsen. Pada sisi produksi juga telah dijelaskan bahwa mekanisme zakat pada hakikatnya menjaga transaksi di pasar agar barang hasil produksi terus dapat diserap oleh pasar.

Para produsen yang nota bene sebagai muzakki dalam mekanisme zakat, akan memastikan diri mereka selalu memberikan hak kaum miskin berupa zakat. Dengan melakukan itu berarti para produsen sekaligus menjaga pasar barang-barang hasil produksinya, dan kemudian secara jangka panjang akan mampu mengembangkan usahanya pada tingkat yang lebih baik.

Lebih lanjut Monzer Kahf (1999) ${ }^{7}$, mengungkapkan bahwa zakat memiliki pengaruh yang positif pada tingkat tabungan dan investasi. Peningkatan tingkat tabungan akibat peningkatan pendapatan akan menyebabkan tingkat investasi juga meningkat.

\footnotetext{
${ }^{7}$ Monzer Kahf, op.cit.
} 
Karena ada preseden bahwa zakat juga dikenakan pada tabungan yang mencapai batas minimal terkena zakat (nisab). Dengan tujuan mempertahankan rasio tabungannya maka tentu investasi menjadi salah satu jalan keluar bagi para muzakki, sehingga secara otomatis meningkatkan angka investasi secara keseluruhan.

Disamping itu Kahf juga mengungkapkan bahwa zakat cenderung menurunkan risiko kredit macet, karena salah satu alokasi dana zakat adalah menolong orang-orang yang terjebak hutang. Sehingga secara riil zakat juga kemudian menekan tingkat pengangguran. Dan menurut Kahf peningkatan jumlah tenaga kerja yang aktif di ekonomi melalui dua mekanisme. Pertama, implementasi zakat itu sendiri membutuhkan tenaga kerja dalam pengelolaannya. Kedua, perubahan golongan mustahik yang awalnya tidak memiliki akses pada ekonomi menjadi golongan yang lebih baik secara ekonomi, tentu saja meningkatkan angka partisipasi tenaga kerja.

Dalam ekonomi Islam, produksi mempunyai motif kemaslahatan, kebutuhan dan kewajiban. Demikian pula, konsumsi. Perilaku produksi merupakan usaha seseorang atau kelompok untuk melepaskan dirinya dari kefakiran. Menurut Yusuf Qardhawi (1995), secara eksternal perilaku produksi dimaksudkan untuk memenuhi kebutuhan setiap individu sehingga dapat membangun kemandirian ummat. Sedangkan motif perilakunya adalah keutamaan mencari nafkah, menjaga semua sumber daya (flora-fauna dan alam sekitar), dilakukan secara profesional (amanah \& itqan) dan berusaha pada sesuatu yang halal. Karena itu dalam sebuah perusahaan ${ }^{8}$ misalnya, menurut M.M. Metwally(1992) asumsi-asumsi produksi, harus dilakukan untuk barang halal dengan proses produksi dan pasca produksi yang tidak menimbulkan ke-madharatan. Semua orang diberikan kebebasan untuk melakukan usaha produksi. ${ }^{9}$

Berdasarkan pertimbangan kemashlahatan (altruistic considerations) itulah, menurut Muhammad Abdul Mannan (1997), pertimbangan perilaku produksi tidak semata-mata didasarkan pada permintaan pasar (given demand conditions) ${ }^{10}$. Kurva permintaan pasar tidak dapat memberikan data sebagai landasan bagi suatu perusahaan

\footnotetext{
${ }^{8}$ Qardhawi,Yusuf. "Peran Nilai dan Moral dalam Perekonomian Islam,” Rabbani Press, Jakarta 1995.

8. Abdul Mannan, Teori dan Praktek Ekonomi Islam, pent. M Mustangin, Yogyakarta: Dana Bakti Wakaf1997

10 . Metwally, M.M. “A Behavioural Model of An Islamic Firm,” Readings in Microeconomics: An Islamic Perspektif, Longman Malaysia 1992
} 


\section{Jurnal Asy-Syukriyyah}

dalam mengambil keputusan tentang kuantitas produksi. Sebaliknya dalam sistem konvensional ada kebebasan untuk berproduksi, namun cenderung terkonsentrasi pada output yang menjadi permintaan pasar (effective demand), sehingga dapat menjadikan kebutuhan riil masyarakat terabaikan.

Dari sudut pandang fungsional, produksi atau proses pabrikasi(manufacturing) merupakan suatu aktivitas fungsional yang dilakukan oleh setiap perusahaan untuk menciptakan suatu barang atau jasa sehingga dapat mencapai nilai tambah (value added). Dari fungsinya demikian, produksi meliputi aktivitas produksi sebagai berikut; apa yang diproduksi, berapa kuantitas produksi, kapan produksi dilakukan, mengapa suatu produk diproduksi, bagaimana proses produksi dilakukan dan siapa yang memproduksi?

Berikut akan dijelaskan sekilas mengenai ketujuh aktivitas produksi.

1. Apa yang diproduksi

Terdapat dua pertimbangan yang mendasari pilihan jenis dan macam suatu produk yang akan diproduksi; ada kebutuhan yang harus dipenuhi masyarakat (primer, sekunder, tersier) dan ada manfaat positif bagi perusahan dan masyarakat (harus memenuhi kategori etis dan ekonomi)

2. Berapa kuantitas yang diproduksi; bergantung kepada motif dan resiko

Jumlah produksi di pengaruhi dua faktor; intern dan ekstern; faktor intern meliputi sarana dan prasarana yang dimiliki perusahan, faktor modal, faktor SDM, faktor sumber daya lainnya. Adapun faktor ekstern meliputi adanya jumlah kebutuhan masyarakat, kebutuhan ekonomi, market share yang dimasuki dan dikuasai, pembatasan hukum dan regulasi.

3. Kapan produksi dilakukan

Penetapan waktu produksi, apakah akan mengatasi kebutuhan eksternal atau menunggu tingkat kesiapan perusahaan.

4. Mengapa suatu produk diproduksi ?;

a. Alasan ekonomi

b. Alasan kemanusiaan

c. Alasan politik

5. Dimana produksi itu dilakukan

a. Kemudahan memperoleh suplier bahan dan alat-alat produksi 
b. Murahnya sumber-sumber ekonomi

c. Akses pasar yang efektif dan efisien

d. Biaya-biaya lainnya yang efisien

6. Bagaimana proses produksi dilakukan: input- proses - out put - out come

7. Siapa yang memproduksi; negara, kelompok masyarakat, indovidu

Dengan demikian masalah barang apa yang harus diproduksi (what), berapa jumlahnya (how much), bagaimana memproduksi (how), untuk siapa produksi tersebut (for whom), yang merupakan pertanyaan umum dalam teori produksi tentu saja merujuk pada motifasi-motifasi Islam dalam produksi.

\section{Zakat dan Prilaku Sosial}

Zakat dengan institusi amil zakat menjaga hubungan yang baik antara si miskin dan si kaya, tanpa perlu mengorbankan harga diri golongan miskin, disebabkan mekanisme distribusi zakat yang melalui baitul mal. Kerelaan dan keikhlasan golongan kaya (muzakki) dalam menyisihkan sebagian hartanya bagi saudaranya yang kurang mampu (mustahik), memberikan suasana pergaulan sosial yang hangat dan terpelihara ketenangannya, sehingga tidak akan tercipta suasana yang kurang harmonis diantara keduanya. Begitu juga dengan efek negatif dari kesenjangan yang amat dalam antara kaya dan miskin seperti meningkatnya kriminalitas, kemaksiatan dan segala tingkah laku negatif, akan dengan signifikan tereduksi. Dengan kata lain zakat kemudian memiliki korelasi yang positif dalam menekan baik gejolak social maupun gejolak politik.

Timur Kuran dalam sebuah artikelnya membahas peran dan fungsi zakat ini secara kritis. Kuran berpendapat bahwa data sejarah menunjukkan bahwa zakat lebih berperan sebagai alat politik dari pada alat ekonomi, sebab zakat lebih efektif menjaga kestabilan politik dibandingkan alat peningkat produktivitas dalam sebuah bangunan ekonomi. Namun oleh Monzer Kahf (1992) ${ }^{11}$ kecenderungan fungsi zakat tersebut dapat dibantah. Kahf mengatakan bahwa melalui golongan masyarakat penerima (mustahik) dan pembayar (muzakki), zakat memiliki peran dalam mendorong kinerja ekonomi. Menurut Kahf, zakat yang diterima oleh mustahik akan meningkatkan konsumsinya yang tentu kemudian meningkatkan agregat permintaan secara makro. Sementara itu pada pihak muzakki, zakat akan meningkatkan rasio simpanan mereka, dengan asumsi bahwa tiap individu akan

\footnotetext{
${ }^{11}$ Monzer Kahf, op. cit.,pp. 101.
} 
mempertahankan tingkat kekayaannya. Jadi peningkatan rasio tabungan, menurut Kahf merupakan kompensasi dari pembayaran zakat. Dan peningkatan rasio tabungan ini memiliki hubungan yang erat dalam peningkatan investasi dari muzakki. Peningkatan output akibat naiknya tingkat konsumsi mustahik membuat muzakki melakukan (keputusan) investasi. Sehingga pada saat yang sama akan meningkatkan pemintaan agregat.

Penanggungan kebutuhan hidup minimal tidak hanya diberikan pada masyarakat Islam saja (meskipun sumbernya bukan dari zakat), masyarakat non-Islam pun dapat memperoleh jaminan tersebut. Hal ini tergambar dari perjanjian pedamaian untuk penduduk Hairah di Irak yang ditulis Khalid bin walid pada masa pemerintahan Abu Bakar r.a. Dalam perjanjian tersebut jaminan kebutuhan hidup minimal diberikan oleh Baitul Mal kepada setiap orang tua yang tak kuat bekerja, cacat atau fakir-miskin dan dihapuskan kewajiban membayar jizyah sepanjang ia tinggal di negara Islam ${ }^{12}$.

\section{Zakat dan Institusi Baitul Mal}

Institusi Baitul Mal sebagai bendahara negara atau departemen keuangan negara (treasury house of the state) tentu saja memasukkan zakat sebagai pos penerimaan dalam anggarannya. Keberadaan baitul mal tentu saja merupakan representasi dari Amil sebagai pengelola zakat. Dan dengan format sistem zakat yang wajib, maka mau tak mau kendali pengelolaan zakat tentu saja sangat efektif ada di bawah negara. Ada beberapa alasan mengapa institusi Baitul Mal sangat dibutuhkan dalam meknisme zakat ini.

1. Dilihat dari mekanisme zakat institusi Baitul Mal merupakan konsekwensi dari eksistensi pengakuan pemungut atau pengelola zakat (Amil).

2. Faktor kebutuhan pertanggung jawaban dan profesionalitas dari pengelolaan serta distribusi dana zakat.

3. Negara memerlukan institusi yang profesional dan sistematis dalam menjalankan fungsi negara sebagai penjamin kesejahteraan warganya menggunakan instrumen fiskal, terutama Zakat.

4. Menjaga harmonisasi hubungan golongan masyarakat kaya dan golongan masyarakat miskin. Dalam hal ini penyaluran hak golongan miskin dari golongan

${ }^{12}$ Yusuf Qardhawi, op. cit., p. 421. 
kaya tidak langsung, sehingga harga diri kedua golongan, terutama golongan miskin, terjaga dengan baik.

Tentu saja baitul mal tidak hanya menampung zakat saja, tapi semua penerimaan negara ditampung dan dikelola oleh baitul mal, seperti Kharaj, Jizyah, Khums, Ushur dan lain-lain. Baitul Mal bukan hanya mengatur tata-laksana pemungutannya tapi juga mengatur pendistribusiannya. Bahkan ada literatur ekonomi klasik yang menyebutkan pada masa Ali bin Abi Thalib, Baitul Mal juga berfungsi mengeluarkan atau mencetak uang Dinar-Dirham bagi kepentingan negara Islam ketika itu. ${ }^{13}$

\section{Perkembangan Kontemporer: Mekanisme Zakat di Indonesia}

Perkembangan Zakat di Indonesia, dimulai secara konstisonal dengan memiliki Undang-Undang tentang zakat yaitu UU No. 38 tahun 1999, karena beriringan dengan perkembangan kebutuhan hukum dalam masyarakat maka diganti dengan UU No. 23 tahun 2011. Dalam UU No.38 tahun 1999 terlihat bahwa dalam undang-undang tersebut tidak wajib bagi para muzakki. Bahkan terkesan undang-undang tersebut adalah sekedar undangundang pengaturan lembaga-lembaga amil zakat saja, bukan undang-undang zakat secara umum.

Dari perbandingan bahasan tentang Pengelolaan Zakat dalam UU No.38 tahun 1999, ada beberapa kelemahan yang memerlukan perbaikan, di antaranya:

1. Sistem zakat yang masih sukarela (voluntary zakat system), terlihat jelas pada pasal 12 ayat 1 UU No. 38 tahun 1999. Sehingga wajar ketika fokus sanksi daru UU ini ada pada badan amil zakat (bab VII Pasal 21). Sebaiknya system zakat diusahakan untuk berada pada posisi wajib (obligatory zakat system), sehingga zakat akan berfungsi dengan maksimal menjalankan perannya sebagai instrumen ekonomi.

2. Sistem zakat yang mekanismenya masih di bawah Departemen Agama. Seperti yang telah disebutkan bahwa zakat merupakan instrumen ekonomi, maka efektifitasnya akan lebih terasa ketika ia benar-benar menjadi alat kebijakan ekonomi. Dengan demikian sebaiknya mekanisme zakat ini berada di bawah otoritas ekonomi. Tapi kondisi poin kedua ini menuntut terpenuhinya kondisi pada poin pertama terlebih dahulu.

\footnotetext{
${ }^{13}$ Hasanuzzaman, Op. cit.
} 


\section{Jurnal Asy-Syukriyyah}

Hal yang menarik dalam Pengelolaan Zakat pada dengan UU No. 23 tahun 2011 terdapat tiga hal yang menjadi perdebatan dalam UU Pengelolaan Zakat, yaitu sentralisasi pengelolaan zakat, kriminalisasi lembaga amil zakat, dan persyaratan lembaga pengelola zakat. Pasal 5 Ayat (1) UU No.23/2011 yang menyatakan Badan Amil Zakat Nasional (Baznas) merupakan operator tunggal pengelolaan zakat. Jika hal itu diterapkan, ada dikhawatirkan akan melemahkan peran lembaga amil zakat (LAZ) serta pengelola zakat tradisional yang selama ini kehadirannya sangat strategis, dengan alasa bahwa jumlah zakat yang dihimpun dari kabupaten/kota se-Indonesia mencapai Rp348 miliar. Dengan perincian, jumlah yang dihimpun Baznas sebesar Rp102 miliar, Bazda Rp26 miliar, dan LAZ sebesar Rp219 miliar. dimana, sekitar dua per tiga atau 63 persen dana zakat yang masuk dihimpun LAZ. Karena itu, perlu menjadi pertimbangan seperti apa tingkat penerimaan dan kepercayaan publik terhadap Baznas jika diputuskan sebagai pengelola tunggal zakat.

Kemudian, dalam undang-undang itu dinyatakan pengelolaan zakat tanpa izin pemerintah berwenang dapat diberi sanksi berupa pidana penjara paling lama lima tahun dan denda maksimal Rp 500 juta dimana akan merugikan pengelola zakat tradisional yang kehadirannya telah eksis jauh sebelum undang-undang di buat.Selain itu, dalam undangundang itu diatur persyaratan lembaga pengelola zakat yang harus mendapat izin menteri dan harus memiliki badan hukum. Aturan ini jelas akan memberatkan bagi LAZ sehingga kehadirannya menjadi terbatas, sisi lemah tersebut perlu ditinjau ulang lebih bijak agar tidak menjadi persoalan dalam persoalaan pengelolaan zakat.

\section{Penerapan Sistem Fiskal \\ 1. Kharaj}

Kharaj merupakan pajak khusus yang diberlakukan Negara atas tanah-tanah produktif yang dimiliki rakyat. Bahkan pada kasus tertentu Negara memiliki hak untuk menyita tanah yang berpotensi namun ditelantarkan oleh pemiliknya atas dasar alasan kemashlahatan. Besarnya pajak jenis ini menjadi hak Negara dalam penentuannya. Dan Negara sebaiknya menentukan besarnya pajak ini berdasarkan kondisi perekonomian yang ada. Dengan karakteristiknya seperti ini, kharaj dapat menjadi instrumen fiskal yang dapat diandalkan oleh negara untuk mendukung programprogram pembangunan negara. 


\section{Jurnal Asy-Syukriyyah}

Hasanuzzaman mengungkapkan bahwa pajak tanah ini terbagi menjadi dua jenis, yaitu pajak Ushr dan pajak Kharaj. Pajak ushr dikenakan pada tanah di jazirah arab, baik yang diperoleh secara turun temurun maupun dengan penakhlukan. Sedangkan pajak kharaj dikenakan pada tanah diluar jazirah arab. Sementara Abu Yusuf berpendapat bahwa setiap tanah yang pemiliknya masuk Islam adalah tanah ushr, dan diluar itu, seperti tanah orang-orang asing yang telah didamaikan penduduknya dan menjadi tanggungan umat Islam, maka tanah itu adalah kharaj.

Dilihat dari jenis kontribusi tanah pada negara, Abu Ubayd mengklasifikasikan tanah menjadi tiga jenis. Pertama tanah yang pemiliknya masuk Islam, yaitu tanah ushr. Kedua tanah yang dikuasai dengan perdamaian atau kesepakatan dengan pajak (kharaj) yang telah ditentukan, yaitu tanah kharaj. Ketiga tanah yang diambil dengan paksa, yaitu yang direbut oleh kaum muslimin.

Quthb Ibrahim Muhammad mengungkapkan bahwa penetapan tingkat kharaj (pajak tanah) harus memperhatikan variable-variabel sebagai berikut:

1. Jenis Tanah: karena tanah yang bagus, maka tanaman akan subur dan hasilnya lebih baik dari tanah yang buruk.

2. Jenis Tanaman: ada yang harganya tinggi dan ada yang harganya rendah, sehingga jenis tanaman ini juga menentukan tingkat pengenaan kharaj.

3. Pengelolaan Tanah: jika biaya pengelolaan tanah tinggi, maka kharaj yang dikenakan tidak sebesar kharaj yang dikenakan pada pengelolaan tanah yang mengandalkan pengairan dari hujan (biaya rendah).

Quthb Ibrahim Muhammad juga memberikan contoh data sejarah bagaimana masa kekhalifahan Umar bin Khattab memberikan standar kharaj di Irak ketika itu.

Tabel 1

Kharaj di Irak Masa Umar bin Khattab

\begin{tabular}{|c|c|}
\hline Standard & Kharaj \\
\hline Satu Gantang Gandum Basah & 2 Dirham \\
\hline Satu Gantang Jagung Basah & 4 Dirham \\
\hline Satu Gantang Anggur Basah & 5 Dirham \\
\hline Satu Gantang Kayu Krom Basah & 10 Dirham \\
\hline
\end{tabular}




\section{Jurnal Asy-Syukriyyah}

Sementara Hasanuzzaman berpendapat bahwa sejarah ekonomi Islam menunjukkan bahwa tingkat kharaj yang umum adalah satu dinar dari setiap empat aroura (ukuran luas tanah ketika itu). Hasanuzzaman juga menunjukkan bagaimana Islam melihat kepemilikan tanah beserta hak pengelolaannya merupakan faktor penting dalam ekonomi. Menjadi kesepakatan ekonomi bahwa tanah merupakan faktor produksi yang paling produktif, sehingga kepemilikan dan pengelolaannya menjadi perhatian penting dalam ekonomi. Dan Islam memberikan perhatian yang cukup pada kepemilikan dan pengelolaan tanah ini.

Menurut Hasanuzzaman, meskipun Islam mengakui adanya hak kepemilikan pribadi atas tanah namun ada beberapa kondisi yang kemudian membuat seseorang terputus hak kepemilikan tanahnya. Hasanuzzaman memaparkan enam kondisi pengambil alihan atau terputusnya hak kepemilikan tanah tersebut.

1. Pemberian hak kepemilikan dari negara yang bersifat temporer, artinya jika sampai pada masa akhir kesepakatan atau terjadi kondisi tertentu, maka hak kepemilikannya kembali pada negara. Hal ini terjadi ketika Umar bin Khattab r.a menarik kembali hak kepemilikan tanah di Mesir ketika pemiliknya wafat.

2. Negara memberlakukan undang-undang baru (amandemen) dalam pembagian tanah kepada rakyat.

3. Pemilik tidak memberdayakan tanah tersebut dalam beberapa waktu tertentu. Dalam kasus ini Quthb Ibrahim Muhammad mengungkapkan pada masa khalifah Umar bin Khattab ada ketentuan bahwa jika seseorang membuka lahan mati maka lahan tersebut menjadi miliknya, namun jika pemilik tersebut menelantarkan lahan itu selama tiga tahun, maka gugur hak kepemilikan atas tanah tersebut.

4. Pemilik tak sanggup membayar sejumlah uang yang menjadi kesepakatan antara negara dengan pemilik tersebut, sebagai syarat dari keberlangsungan hak kepemilikan. Ini terjadi pada kasus Hilal Bani Muta'an yang melakukan perjanjian dengan Rasulullah.

5. Kepentingan negara yang begitu mendesak untuk mengambil alih hak kepemilikan lahan tertentu. Ini terjadi pada kasus penduduk Najran dan Fadak pada masa Umar bin Khattab. 
6. Atas alasan kemashlahatan atau demi kepentingan publik, kepemilikan tanah dapat saja diambil alih oleh negara. Seperti kasus perluasan masjid Nabawi di Madinah.

Untuk masalah pertanahan ini, Quthb Ibrahim Muhammad mengungkapkan bahwa negara juga dapat mengelola tanah yang diberikan hak penjagaan dan perlindungannya oleh rakyat. Tanah petakan dibawah perlindungan negara ini di kenal dengan Al Hima. Penggunaannya tentu saja untuk kepentingan negara atau publik, seperti program pertahanan keamanan, pengentasan kemiskinan dan lain sebagainya.

Dalam konteks perekonomian modern, kharaj juga menjadi sebuah instrumen yang penting dalam penerimaan modal pembangunan. Inovasi kebijakan fiskal menggunakan kharaj sebagai rujukan merupakan sebuah keharusan dalam perekonomian modern saat ini. Misalnya bagaimana menyikapi orang-orang yang tidak memiliki tanah produktif tapi mempunyai pendapatan yang begitu besar, mungkin akan lebih mashlahat jika inovasi kebijakan pajak menganalogikan penarikan pajak menggunakan pendekatan kharaj ini, ketimbang menganalogikan pada zakat. Karena karakteristik pendistribusian kharaj lebih bebas daripada pendistribusian zakat yang terikat pada golongan tertentu. ${ }^{14}$

Namun tentu saja haruslah disepakati interpretasi dalil-dalil syariat yang mengatur tentang kharaj ini serta aplikasinya di perekonomian modern. Sehingga implementasi instrumen ini bagi negara akan maksimal dan tepat sasaran.

\section{Jizyah}

Jizyah (poll tax) merupakan pajak yang hanya diperuntukkan bagi warga negara bukan muslim yang mampu. Berdasarkan banyak literatur klasik ekonomi Islam, pajak jenis ini dikenakan pada warga negara non muslim laki-laki. Bagi yang tidak mampu seperti mereka yang uzur, cacat dan mereka yang memiliki kendala dalam ekonomi akan terbebas dari kewajiban ini. Bahkan untuk kasus tertentu Negara harus memenuhi kebutuhan penduduk bukan muslim tersebut akibat ketidak mampuan mereka memenuhi kebutuhan minimalnya, sepanjang penduduk tersebut rela dalam pemerintahan Islam. Hal ini berkaitan erat dengan fungsi pertama dari Negara yang

\footnotetext{
${ }^{14}$ Hasanuzzaman
} 


\section{Jurnal Asy-Syukriyyah}

telah dijelaskan sebelumnya, yaitu memenuhi kebutuhan minimal rakyatnya. Jadi pemenuhan kebutuhan tidak terbatas hanya pada penduduk muslim saja.

Quthb Ibrahim Muhammad dan Hasanuzzaman serta beberapa pakar sejarah ekonomi Islam klasik mengungkapkan bahwa jizyah ini rata-rata dikenakan pada setiap laki-laki dewasa non-muslim sebesar 2 dinar. Golongan laki-laki dewasa ini pada hakikatnya adalah golongan non-muslim Dzimmah, yang disebut dzimmi. Secara atimologis dzimmah memiliki definisi perjanjian dan perlindungan, jadi kaum dzimmi adalah mereka yang melakukan perjanjian untuk berlindung di bawah pemerintahan Islam. Ada beberapa pendapat tentang jumlah jizyah yang harus dikenakan pada kaum dzimmi, dapat dilihat pada dua table yang bersumber dari Quthb Ibrahim Muhammad dan Hasanuzzaman. Alasan variasi tingkat Jizyah yang harus dibayar di Mesir tidak diungkapkan secara jelas, padahal pengenaan tingkat Jizyah rata-rata adalah 2 dinar perkepala.

Table 2

Standard Jizyah Masa Umar bin Khattab

\begin{tabular}{|c|c|}
\hline Standard & Jizyah \\
\hline Penghasilan Tinggi & 48 Dirham \\
\hline Penghasilan Menengah & 24 Dirham \\
\hline Penghasilan Rendah & 12 Dirham \\
\hline
\end{tabular}

Sumber: Quthb Ibrahim Muhammad

Tabel 3

Tingkat Jizyah di Mesir (103 Hijriah)

\begin{tabular}{|c|c|}
\hline Jumlah Wajib Jizyah & Jizyah dalam Dinar \\
\hline 95 & 230 \\
\hline 5 & $71 / 6$ \\
\hline 7 & 17 \\
\hline 15 & $38^{1 / 2}$ \\
\hline 7 & $20^{1 / 2}$ \\
\hline 5 & 13 \\
\hline 12 & $251 / 6$ \\
\hline 14 & $1082 / 3$ \\
\hline
\end{tabular}

Sumber: Hasanuzzaman (1991) 


\section{Jurnal Asy-Syukriyyah}

Menurut Hasanuzzaman, variasi pengenaan tingkat kharaj bagi warga negara kemungkinan besar disebabkan oleh luas lahan yang dimiliki, namun relatif susah menemukan alasan atas variasi tingkat jizyah yang dikenakan pada golongan dzimmi (lihat table tingkat jizyah di Mesir).

Dalam konteks ekonomi kontemporer, mungkin tidak lagi pengenaan jizyah hanya terbatas pada golongan laki-laki non-muslim, tapi juga pada non-muslim wanita yang mampu. Apalagi masa sekarang ini, sudah menjadi kelaziman bahwa wanita juga dapat bekerja dan memperoleh pendapatan yang cukup besar.

\section{Ushur}

Ushur merupakan pajak khusus yang dikenakan atas barang niaga yang masuk ke Negara Islam (impor). Menurut Umar bin Khattab, ketentuan ini berlaku sepanjang ekspor Negara Islam kepada Negara yang sama juga dikenakan pajak ini. Dan jika dikenakan besarnya juga harus sama dengan tarif yang diberlakukan negara lain tersebut atas barang Negara Islam. Jadi ada perbedaan di sini antara Ushur dan Ushr. Ushr sendiri lebih tepat definisinya apa yang telah dijelaskan pada bahasan kharaj di atas. Menurut Hasanuzzaman Ushur (bentuk jamak dari ushr) berasal dari ungkapan pajak sepuluh persen dari nilai barang (ada yang mengungkapkan satu dirham per transaksi yang terjadi) yang dikenakan atas pedagang pada masa sebelum Islam, dan petugas ushur ini dekanal dengan sebutan ashir.

Beberapa hadits menyebutkan Rasulullah melarang praktek ashir ini. Meskipun pada masa Umar bin Khattab praktek ini dilakukan kembali, namun asas dan bentuknya tidak sama dengan praktek ashir sebelum masa sebelum Islam. Masih menurut Hasanuzzaman, Abu Ubayd mengungkapkan bahwa praktek ashir telah diganti oleh Rasulullah dengan zakat, sehingga ushur pada hakikatnya dikenakan hanya pada kaum pedagang kafir Harbi; kaum kafir yang menentang dan memerangi Islam dan Dzimmi; kaum kafir yang tidak memusuhi dan memerangi Islam. Besarnya ushur yang dikenakan adalah sepuluh persen bagi pedagang harbi, lima persen bagi pedagang dzimmi dan dua setengah persen bagi pedagang muslim (zakat). 


\section{Jurnal Asy-Syukriyyah}

\section{Infaq-Shadaqah-Wakaf}

Infaq-Shadaqah-Wakaf merupakan pemberian sukarela dari rakyat demi kepentingan ummat untuk mengharapkan ridha Allah SWT semata. Namun oleh Negara dapat dimanfaatkan dapat digunakan Negara dalam melancarkan proyekproyek pembangunan Negara. Pada kondisi keimanan rakyat yang begitu baik maka dapat saja (besar kemungkinannya) penerimaan negara yang berasal dari variabel sukarela ini akan lebih besar dibandingkan dengan variabel wajib, sepanjang faktorfaktor produksi digunakan pada tingkat yang maksimal. Khusus wakaf, dengan karakteristik kepemilikan publik yang permanen atas benda wakaf, maka semakin besar wakaf akan semakin kecil biaya sosial yang harus ditanggung oleh rakyat dalam ekonomi mereka. Sebab wakaf terikat pada fungsi publik yang di syaratkan oleh syariat. Menurut Ahmed Faridi, penerimaan dari pos sukarela ini memiliki korelasi yang positif dengan kondisi keimanan warga negara, semakin beriman warga negara, semakin besar penerimaan negara melalui pos ini dalam membiayai pembangunan negara.

\section{Ghanimah}

Ghanimah merupakan pendapatan Negara yang didapat dari kemenangan perang. Penggunaan uang yang berasal dari ghanimah ini, ada ketentuannya dalam Al Qur'an. Distribusi ghanimah empat perlimanya diberikan pada para prajurit yang bertempur, sementara seperlimanya adalah khums (lihat penjelasan tentang khums). Hasanuzzaman mendefinisikan ghanimah sebagai segala barang bergerak yang direbut oleh tentara muslim dalam sebuah pertempuran. Dalam ghanimah ada beberapa jenis pembagian yang harus menjadi perhatian. Nafal, yaitu penghargaan yang diberikan pada seorang prajurit berupa pembagian harta ghanimah, yang jumlahnya lebih dari rata-rata, dari pemimpinnya, baik pemimpin negara maupun pemimpin lapangan. Pembagan nafal dapat dilakukan meskipun tidak ada janji oleh negara pada awalnya ${ }^{15}$. Salab barang pribadi yang direbut oleh prajurit dari musuh yang dibunuhnya. Dan Safi' adalah barang pilihan pemimpin yang diambil dari ghanimah untuk dirinya sendiri.

${ }^{15}$ Op. cit., pp. 150 


\section{Khums}

Khums adalah satu perlima bagian dari pendapatan (ghanimah) akibat dari ekspedisi militer yang dibenarkan oleh syariah, dan kemudian pos penerimaan ini kemudian dapat digunakan negara untuk program pembangunannya. Dalam alqur'an (Al Anfal: 41) dijelaskan bagaimana penggunaan penerimaan negara dari pos Khums ini.

"Ketahuilah, sesungguhnya apa saja yang dapat kamu peroleh sebagai rampasan perang (ghanimah), maka sesungguhnya seperlima untuk Allah, Rasul, kerabat Rasul, anak-anak yatim, orang-orang miskin dan ibnussabil...” (Al Anfal: 41)

\section{Fay'}

Menurut Muhammad Nejatullah Siddiqi, harta fay' merupakan pendapatan Negara selain yang berasal dari zakat. Jadi termasuk didalamnya; kharaj, jizyah, ghanimah, ushr dan pendapatan-pendapatan dari usaha-usaha komersil pemerintah (misalkan pendapatan yang berasal dari perusahaan milik pemerintah). Definisi ini lebih mempertimbangkan kondisi ekonomi kontemporer saat ini yang strukturnya cukup berbeda dengan keadaan pada masa Rasulullah dulu.

Abidin Ahmad Salama (1995) ${ }^{16}$ menyebutkan bahwa pendapatan negara ada yang bersumber dari Al Mustaglat (government investment). Sumber pendapatan ini termasuk sumber baru bagi negara yang diperkenalkan oleh Walid bin Abdul Malik. Walid mendirikan departemen baru dalam pemerintahan yang bertanggung jawab terhadap investasi yang dilakukan oleh negara.

Sementara itu Hasanuzzaman mendefinisikan harta fay' berdasarkan interpretasi masa Rasulullah, yaitu harta kekayaan negara musuh yang telah dikalahkan (di dapat bukan melalui peperangan atau di medan perang), yang kemudian dimiliki dan dikelola oleh negara Islam. Dengan demikian dalam fay ada unsur ghanimah dan bukan ghanimah, sementara dalam ghanimah ada khums (1/5 bagian) dan ada yang menjadi hak mujahidin (4/5 bagian).

\footnotetext{
${ }^{16}$ Abidin Ahmad Salama, Fiscal Policy of An Islamic State, Readings in Public Finance in Islam, (Edited by Mahamoud A. Gulaid \& Mohamed Aden Abdullah), Islamic Research and Training Institute (IRTI) - Islamic Development Bank (IDB), Jeddah, Kingdom of Saudi Arabia, 1995, pp. 48
} 


\section{Jurnal Asy-Syukriyyah}

\section{Pajak Khusus}

Pajak ini penentuan pemungutannya tergantung kondisi perekonomian Negara, dan menjadi hak prerogative Negara dalam memutuskan besar pajak yang akan dipungut. Misalnya dalam menjalankan fungsi Negara yang pertama, yaitu memenuhi kebutuhan minimal penduduk, ketika zakat dan harta fay' tidak cukup dalam mewujudkan fungsi tersebut, maka kebijakan selanjutnya Negara dapat mengenakan pajak khusus yang dikenakan pada sekelompok orang kaya diantara masyarakat. Perlu diingat bahwa kebijakan ini sifatnya kondisional atau incidental, ia sesuai dengan keadaan keuangan Negara dalam menjalankan kewajibannya. Artinya pajak menjadi instrumen komplementer dari instrumen yang telah lazim ada dalam perekonomian negara Islam.

Dengan keadaan perekonomian kontemporer saat ini, yaitu perekonomian di banyak negara Islam dalam keadaan tidak begitu baik, dimana mekanisme zakat tidak berjalan sesuai dengan format yang orisinil (obligatory zakat system) sehingga tidak dapat diharapkan mampu menjalankan fungsi negara dalam menjamin kebutuhan dasar warga negara, begitu juga pendapatan negara yang lain, maka pengenaan pajak menjadi jalan keluar yang cukup efektif (meskipun pelaksanaan pajak ini lebih dimotivasi oleh alasan pengetahuan menjalankan system fiscal konvensional). Jadi dalam keadaan transisi seperti ini rasanya cukup bijak jjika negara-negara Islam mulai menerapkan mekanisme pajak yang memiliki karakteristik seperti instrumen fiskal dalam perekonomian Islam.

\section{Lain-lain}

Penerimaan negara dapat juga bersumber dari variable seperti warisan yang memiliki ahli waris, hasil sitaan, denda, hibah atau hadiah dari negara sesama Islam, hima dan bantuan-bantuan lain yang sifatnya tidak mengikat baik dari negara luar maupun lembaga-lembaga keuangan dunia.

Dari penjelasan instrumen fiskal ini perlu dipahami bahwa setiap instrumen memiliki karakteristiknya masing-masing. Baik pemungutannya (penerimaan bagi negara) maupun penggunaannya (pengeluaran bagi negara). Dilihat dari aturan pemungutannya ada instrumen fiskal yang sifatnya menjadi ketentuan yang mengikat (regulated), maksudnya instrumen tersebut dikenakan pada objek pembayar tertentu dengan sanksi-sanksi tertentu dari negara bagi yang tidak membayar kewajibannya, misalnya instrumen Zakat, Kharaj, 
Jizyah dan Ushur. Pada Zakat, pemungutannya dilakukan hanya pada masyarakat yang harta wajib zakatnya melebihi batas nisab (batas minimal harta terkena Zakat). Ada juga instrumen yang bersifat sukarela seperti Infaq, Shadaqah dan Wakaf. Sedangkan instrumen yang bersifat kondisional dapat berupa Khums, Pajak, Fay' dan lain-lain. Instrumen terakhir ini sangat ditentukan oleh kondisi-kondisi perekonomian yang ada di sebuah negara. Misalnya karena kondisi perekonomian mengalami krisis yang cukup lama sehingga sebagian besar rakyat terancam tidak dapat terpenuhi kebutuhan dasarnya, maka negara boleh secara syariat memungut pajak. Dan pajak tersebut hanya boleh dikenakan pada golongan masyarakat yang kaya.

Begitu juga pada mekanisme penggunaan dana-dana tadi. Ada instrumen yang penggunaan dananya bersifat terikat dan bersifat tidak terikat atau bebas. Penggunaan yang bersifat terikat maksudnya penggunaan yang harus merujuk pada petunjuk yang telah ditetapkan oleh dalil-dalil syariat, misalnya instrumen Zakat, dimana penggunaan dananya hanya terbatas pada delapan golongan masyarakat (mustahik). Sedangkan penggunaan instrumen fiscal yang bersifat tidak terikat artinya akumulasi dana yang bersumber dari instrumen tersebut dapat digunakan untuk hal-hal apa saja dalam pembangunan negara, tergantung pada prioritas pembangunan yang ada. Misalnya dana yang bersumber dari fay', infaq, shadaqah dan wakaf (yang bersifat mutlak atau tidak terikat).

Kedisiplinan pengelolaan dana dari instrumen fiskal Islam ini terlihat cukup menonjol. Hal ini sebenarnya menunjukkan betapa perekonomian dalam Islam begitu memperhatikan terjamin dan terjaganya segala kepentingan individu dan kolektif yang secara otmatis dapat memelihara kestabilan social masyarakat Islam. Sehingga dalam keadaan tersebut masyarakat secara individu dan kolektif dapat melaksanakan peran dan fungsinya sebagai hamba Allah SWT yaitu ibadah secara baik dengan hasil yang maksimal. Secara tidak langsung karakteristik ini menguatkan pendapat bahwa setiap instrumen fiskal memiliki "sasaran tembaknya" masing-masing dalam perekonomian Islam.

Kedisiplinan ini juga yang secara implicit diungkapkan oleh Sahabat Ali bin Abi Thalib r.a ketika menjawab pertanyaan Sahabat Umar bin Khattab r.a berkaitan dengan desakan para sahabat yang lain pada Umar agar menggunakan perhiasan Ka'bah untuk pembiayaan perang. Ali bin Abi Thalib r.a mengatakan:

“Al Qur'an telah diturunkan kepada Nabi SAW dan Harta itu terbagi empat; harta kaum muslimin, maka bagilah antara para ahli waris menurut ilmu fara'idh (ilmu waris); dan harta fay', maka bagikanlah kepada mereka yang berhak; sedangkan harta 
seperlima ghanimah (khums), maka bagikanlah kepada apa yang Allah inginkan; dan untuk zakat, tempatkanlah menurut yang Allah kehendaki."

\section{Kesimpulan}

Mekanisme zakat memastikan aktifitas ekonomi dapat berjalan pada tingkat yang minimal yaitu pada tingkat pemenuhan kebutuhan primer, sedangkan infak-shadaqah dan intsrumen sejenis lainnya mendorong permintaan secara agregat, karena fungsinya yang membantu ummat untuk mencapai taraf hidup diatas tingkat minimum. Karena oleh negara infak-shadaqah dan instrumen sejenisnya inilah yang melalui bitul mal digunakan untuk mengentaskan kemiskinan melalui program-program pembangunan. Jadi zakat dan infakshadaqah memiliki perannya masing-masing. Pada kondisi ummat yang baik dimana tingkat keimanannya ada pada level yang baik, maka pendapatan negara yang bersumber dari infak-shadaqah sepatutnya lebih besar dari penerimaan zakat.

Dalam membahas prilaku konsumsi dari individu muslim, karakteristik zakat sudah nampak terlihat, bahwa zakat merupakan instrumen ekonomi yang vital. Peghilangan mekanisme zakat dalam perekonomian akan merusak keseimbangan ekonomi, bahkan memiliki pengaruh yang besar pada ketidakseimbangan ekonomi dan sosial. Zakat dengan institusi amil zakat menjaga hubungan yang baik antara si miskin dan si kaya, tanpa perlu mengorbankan harga diri golongan miskin, disebabkan mekanisme distribusi zakat yang melalui baitul mal. Begitu juga dengan efek negatif dari kesenjangan yang amat dalam antara kaya dan miskin seperti meningkatnya kriminalitas, kemaksiatan dan segala tingkah laku negatif, akan dengan signifikan tereduksi.

Beberapa negara yang menerapkan system ekonomi konvensional memiliki instrumen yang berfungsi hampir sama dengan zakat. Beberapa negara (teutama negara barat) menerapkan tunjangan social bagi penduduknya yang tidak memiliki kerja, uzur atau tidak memiliki kemampuan untuk mencari nafkah. Dan sumber pendanaannya adalah berasal dari pajak. Namun karakteistik pajak serta tunjangan social tersebut berbeda sama sekali dengan mekanisme yang ada dalam Zakat. Penjaminan dalam mekanisme zakat merupakan prioritas utama dalam kebijakan ekonomi (ketika zakat tak mampu memenuhi fungsi penjaminan tersebut, maka pemasukan negara dari sumber selain zakat akan digunakan sampai kebutuhan minimal seluruh rakyat terpenuhi). Sedangkan dalam konvensional tunjangan social sangat tergantung pada penerimaan pajak, ketika dana pajak dirasakan tidak mencukupi, maka tunjangan tersebut bukanlah menjadi prioritas yang utama. 


\section{DAFTAR PUSTAKA}

Abdul Mannan, Teori dan Praktek Ekonomi Islam, pent. M Mustangin, Yogyakarta: Dana Bakti Wakaf1997

Abidin Ahmad Salama, Fiscal Policy of An Islamic State, Readings in Public Finance in Islam, (Edited by Mahamoud A. Gulaid \& Mohamed Aden Abdullah), Islamic Research and Training Institute (IRTI) - Islamic Development Bank (IDB), Jeddah, Kingdom of Saudi Arabia, 1995, pp. 48

Paul A. Samuelson dan William D. Nordhaus, Microeconomics (Terjemahan), Fourteen Edition, McGraw-Hill, Erlangga Jakarta, 1992.

Konsep ini diperkenalkan oleh Alfred Marshal dari Cambridge University dan Irving Fisher dari Yale University. Lihat Paul A. Samuelson dan William D. Nordhaus, Microeconomics (Terjemahan), Fourteen Edition, McGraw-Hill, Erlangga Jakarta, 1992.

Monzer Kahf, The Performance of the institution of Zakah in Theory and Practice, The International Conference on Islamic Economics Towards the $21^{\text {st }}$ Century, Kuala Lumpur - Malaysia, April, 1999.

Metwally, M.M. "A Behavioural Model of An Islamic Firm," Readings in Microeconomics: An Islamic Perspektif, Longman Malaysia 1992

Qardhawi,Yusuf. "Peran Nilai dan Moral dalam Perekonomian Islam," Rabbani Press, Jakarta 1995.

Umer Chapra, Monetary Policy in An Islamic Economy, Money and Banking in Islam (Edited by Ziauddin Ahmed, Munawar Iqbal, Fahim Khan), International Center for Research In Islamic Economics, King Abdul Aziz University Jeddah and Institute of Policy Studies Islamabad, Pakistan, 1996, pp. 34.

Ziauddin Ahmed, Munawar Iqbal and Fahim Khan (Editors), Money and Banking In Islam, International Center for Research In Islamic Economics, King Abdul Aziz University Jeddah and Institute of Policy Studies Islamabad, Pakistan, 1996, pp. 17-18. 